$\mathbf{R}_{\text {ESEARCH }} \mathbf{P}_{\text {APER }} \longrightarrow \frac{\text { FOOD SCIENCE }}{\text { RESEARCH JOURNAL }}$

\title{
Quality and acceptability of tripe pickles from goat and buffalo rumen meat
}

\author{
M. AnNa AnANDH
}

\begin{abstract}
Rumen meat otherwise known as tripe is one of the important edible animal by product and the material offers good scope for processing in the products. Traditional styled pickles were prepared from goat and buffalo tripe and were studied for various physico-chemical, microbial and sensory qualities. Significantly $(\mathrm{P}<0.05)$ higher titrable acidity $(\%$ acetic acid $)$, TBA value and fat percentage were observed in goat tripe pickles as compared to buffalo tripe pickles. $\mathrm{pH}$, product yield, moisture and protein contents were significantly $(\mathrm{P}<0.05)$ higher in buffalo tripe pickles as compared to goat tripe pickles. Total plate, coliform and yeast and mould counts of goat tripe pickles were higher as compared to buffalo tripe pickles and values did not differ significantly between them and were within the standards specified for cooked meat products. All sensory scores were significantly $(\mathrm{P}<0.05)$ higher for goat tripe pickles as compared to buffalo tripe pickles. Therefore, it can be concluded that traditional styled tripe pickles prepared from goat and buffalo tripe had better physico-chemical, microbial qualities and sensory scores were rated moderately to highly acceptable.
\end{abstract}

Key Words : Goat, Buffalo, Rumen, Tripe, Pickles, Quality, Acceptability

How to cite this article : Anandh, M. Anna (2017). Quality and acceptability of tripe pickles from goat and buffalo rumen meat. Food Sci. Res. J., 8(1): 123-127, DOI : 10.15740/HAS/FSRJ/8.1/123-127. 